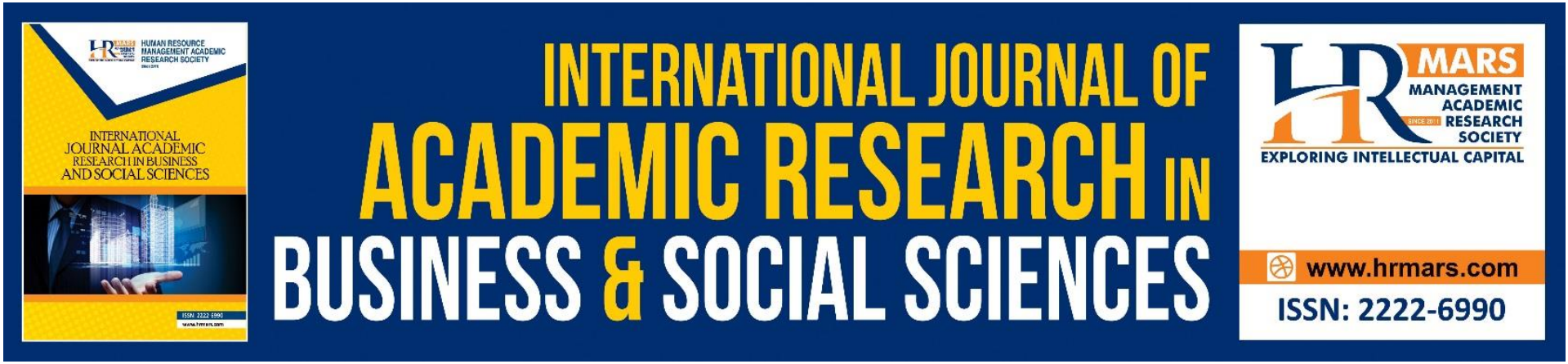

\title{
Assessing Student Inclination for Language Learning Via Open Distance Learning During Covid-19 Pandemic
}

Alice Shanthi, Nur Izzah Jamil, Lim Teck Heng

To Link this Article: http://dx.doi.org/10.6007/IJARBSS/v11-i10/11011

DOI:10.6007/IJARBSS/v11-i10/11011

Received: 07 August 2021, Revised: 10 September 2021, Accepted: 28 September 2021

Published Online: 09 October 2021

In-Text Citation: (Shanthi et al., 2021)

To Cite this Article: Shanthi, A., Jamil, N. I., \& Heng, L. T. (2021). Assessing Student Inclination for Language Learning Via Open Distance Learning During Covid-19 Pandemic. International Journal of Academic Research in Business and Social Sciences, 11(10), 557 - 571.

Copyright: (c) 2021 The Author(s)

Published by Human Resource Management Academic Research Society (www.hrmars.com)

This article is published under the Creative Commons Attribution (CC BY 4.0) license. Anyone may reproduce, distribute, translate and create derivative works of this article (for both commercial and non-commercial purposes), subject to full attribution to the original publication and authors. The full terms of this license may be seen at: http://creativecommons.org/licences/by/4.0/legalcode

Vol. 11, No. 10, 2021, Pg. $557-571$

http://hrmars.com/index.php/pages/detail/IJARBSS

JOURNAL HOMEPAGE

Full Terms \& Conditions of access and use can be found at http://hrmars.com/index.php/pages/detail/publication-ethics 


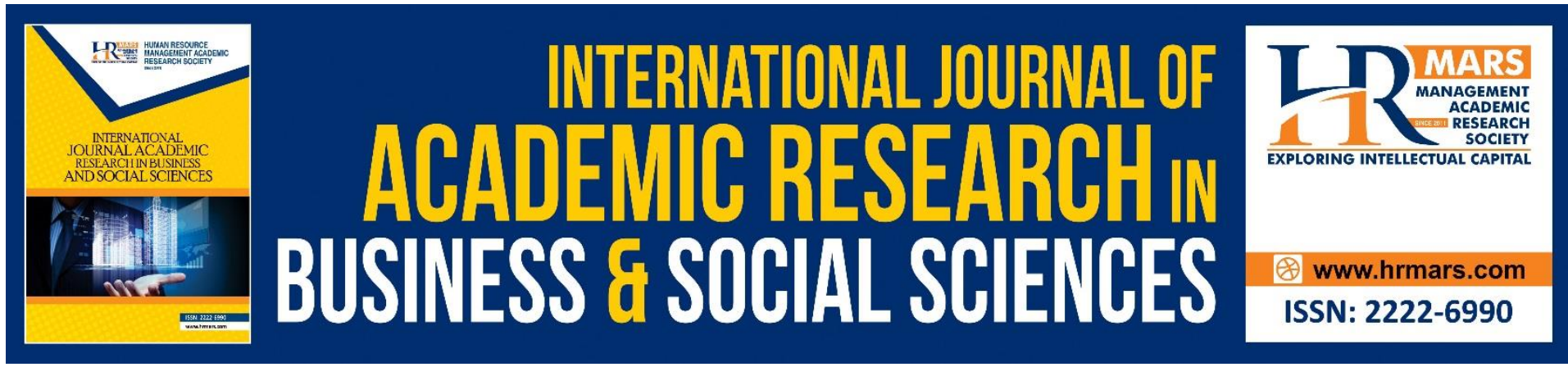

\title{
Assessing Student Inclination for Language Learning Via Open Distance Learning During Covid-19 Pandemic
}

\author{
Alice Shanthi ${ }^{1}$, Nur Izzah Jamil ${ }^{2}$, Lim Teck Heng ${ }^{3}$ \\ ${ }^{1}$ Academy of Language Studies Universiti Teknologi MARA, Negeri Sembilan Branch, \\ Seremban Campus, Malaysia, ${ }^{2}$ Faculty of Computer and Mathematical Sciences, Universiti \\ Teknologi MARA, Negeri Sembilan Branch, Rembau Campus, Malaysia, ${ }^{3}$ Academy of \\ Language Studies Universiti Teknologi MARA, Pulau Pinang Branch, Permatang Pauh \\ Campus, Malaysia \\ Email: aliceshanthi@uitm.edu.my
}

\begin{abstract}
At the end of 2019, the world witnessed a coronavirus outbreak, bringing significant challenges to many sectors, including education. This study aims to examine UiTM students' ability to cope with learning English during the Covid-19 pandemic via ODL. The study looked at students' readiness to learn online thoroughly, their efficiency in fulfilling the syllabus requirements, self-motivation, and computer literacy skills. The instrument measured four factors: computer literacy skills, efficiency, learning readiness, and self-motivation with 5point Likert Scale. Thus, this study computes the sum of item responses over the set of individual items. As for data analysis, the association between these variables was discussed using descriptive statistics, correlation analysis, and multiple linear regression to answer the objectives of this study. Correlation analysis showed a positive correlation between student preference to learn English and computer literacy skills, efficiency, learning readiness, and self-motivation. Regression analysis showed that the four independent variables of the study were statistically significant towards students' preference in taking English courses via ODL. Computer literacy skills contributed the most towards students' preference for ODL for English courses in terms of variable importance.
\end{abstract}

Keywords: Open Distance Learning (ODL), Online Language Learning, Exploratory Factor Analysis, Correlation Analysis, Multiple Linear Regression, Covid 19 Pandemic

\section{Introduction}

The education landscape in Malaysia and around the globe has changed with the dawn of the Covid-19 pandemic. When the World Health Organization (WHO) declared it as a pandemic on 11 March 2020, UNESCO recommended the use of Open and Distance Learning (ODL) and online educational platforms instead of physical classrooms to ensure continuity of the teaching process (Gonzalez et al., 2020). Teaching and learning from the lowest level of primary schools until the university level worldwide has changed from the usual face-to-face or blended form to fully remote learning where learning delivery is entirely online as 
prescribed in ODL. "ODL is flexible and advocates access and multiple modes of knowledge acquisition. ODL is a flexible means with the availability of choices for educational endeavours anywhere, anytime and anyhow". It is also accredited as having provided "opportunity made available to all, freeing them from constraints of time and place, and finally, multiple modes mean the use of various delivery systems and learning resources" (Malaysia Qualification Agency, 2019). This abrupt global change to online platforms has opened many perspectives of areas for research (Javid et al., 2021).

There are indications that this new emerging learning of (via) ODL might be here to stay for a while and lead to more future possibilities and opportunities to use digital platforms for teaching and learning and traditional pedagogy methods. With the routine experience of learning in a physical classroom all their lives, students had to intensify and learn in a different level of commitment with ODL. Pertinent for the present study is to learn how students manage with learning in an entirely virtual platform; for some students, learning in a completely virtual space occurs for the first time in their lives. Other critical aspects of the ODL learning process, such as evaluation or independent learning, can be challenging for students to complete without the direct supervision of teachers (Gonzalez et al., 2020).

Students' comfort with ODL is essential because the difference in language learning during face-to-face where no Internet savviness is needed, compared to a complete mastery of it in ODL may not yield the same results for students (Selvanathan et al., 2020). Concerning $\mathrm{ODL}$, teachers must(should) be aware of students' readiness, efficiency, and motivation to accept and be comfortable to use (in using) the platform as a learning tool. Also, teachers need to know if students possess the necessary skills to follow lectures, complete and submit assignments and take tests online.

Even though universities in Malaysia had incorporated some form of online learning for students before the Covid-19 pandemic came about, the chaos that students and teachers experienced in the initial stages was quite overwhelming (Shanthi et al., 2021; Rizun \& Strzelecki, 2020) . Most public higher learning institutions in Malaysia had incorporated blended learning in the academic teaching and learning process even before the Covid-19 pandemic. Therefore, the advent of fully digital learning or direct online learning (ODL) without any physical classes caught the students and lecturers off guard. According to a study conducted by Shanthi et al (2021), at a local public university, respondents responded to several questions on their readiness to embrace $\mathrm{ODL}$, to a question, 'how often fully online lessons for English proficiency classes were conducted before the Covid-19 pandemic', a whopping $72 \%$ responded that it was conducted between 1 to 3 lessons per semester. This new normal of complete virtual teaching and learning has put enormous pressure on the higher learning institutions to ensure students achieve and acquire knowledge as prescribed in the syllabus and course content (Javid et al., 2021; Yazon and Callo, 2021).

Fortunately, various modern technological tools and resources are available to address the ODL obstacle presented by the COVID-19 pandemic (Malaysia Qualification Agency, 2019). The students used tools such as Google classroom, Microsoft teams, and the institutional UFuture, a Learning Management System (LMS), to learn virtually. Academic subjects formerly taught face-to-face could be modified into audio, videos, or other forms and saved into cloud drives for students to access in ODL (Muda \& Yee, 2019).

The students' perceptions of learning virtually as advocated in ODL are mostly related to students' motivation, readiness and efficiency, and computer skills to complete the English proficiency course by participating in online teaching and learning, completing, and submitting online the required assessments completing test online. 
Presently, evidence has shown that online learning during the pandemic aided students to fare better in their studies. A study conducted by Gonzalez et al. (2020), who investigated students' performance during COVID-19, found that "students improved their performance when compared with a cohort from the previous year." Again, the same study compared the results for the online and face-to-face group of students for specific tests designed for both groups and found "significant improvement in the scores of both modalities, online and faceto-face." Though there are recorded and positive changes in student achievement, there is insufficient data on how the stay-at-home and learn-in-isolation and learn through ODL brought about by COVID-19 have influenced the learning process from the students' perspectives.

Therefore, it is crucial to identify the relationship between students' preference for ODL for English courses and students' readiness, efficiency, motivation, and teaching and learning and assessment tools (Yen, 2020). This paper hopes to provide insights to policymakers and educational administrators to be well informed of the facts about online learning from the students' perspective and its potential impacts on productivity in education. This study specifically looks at the experience of learning English using ODL in a public university in Malaysia. This study also hopes to offer fundamental knowledge to evaluate and comprehend the potential contributions derived from learning English via ODL and shed light on how students embraced the use of ODL, which is questionable.

\section{Open and Distance Learning (ODL) Experience in UiTM}

In line with the intentions of inculcating educational innovations, the Malaysian Ministry of Education, through its Education Blueprint 2015-2025, has launched measures to make online learning an integral component of higher education and lifelong learning (Higher Education: E-16). Heeding this call, the management of UiTM introduced blended learning for all subjects taught in the university. Thus, when the ODL came into play, the academic fraternity was confident that the experience gained by the lecturers in conducting blended learning would enable them to ace ODL during the pandemic time when physical classes were cancelled (Abu Karim, 2020). In UiTM, three leading platforms, namely Google classroom, Microsoft teams, UFuture (institution LMS), and other platforms such as WhatsApp and Telegram, were mainly used to teach and learn English. Despite the teachers' availability and use of different platforms to teach, there were persistent concerns about the ability of the students to learn via ODL, especially those from parts of the country where Internet connectivity was limited (Juhary, 2020; Selvanathan et al. 2020).

To address this concern, UiTM adopted a hybrid online environment where both asynchronous and synchronous were used. An asynchronous virtual classroom is where teachers and students connect and communicate in real-time, as in Google Meet using webcams and chat features in handphones and computers. It is like a conventional classroom, except all participants access it virtually through the Internet, and lessons can be recorded and added to any online platform. The downside of the synchronous method is when students with poor internet connections face the challenge of being present during the virtual classroom (Krishnan et al., 2020).

According to Pervenn (2016), asynchronous e-learning is the most adopted method for online education because learners are not time-bound and can respond at their leisure. On the other hand, in an asynchronous learning environment, students have the advantage of exploring readily available material in the form of audio/video lectures, handouts, articles, and PowerPoint presentations which students could explore according to their pace and time. 
The teaching materials are accessible anytime, anywhere via any online teaching platforms such as UFuture, Google classroom, Microsoft teams, or other channels of the sort. (Perveen, 2016)

When students have inadequate Internet connections in both environments, materials are provided through email or taught via low-data tools like WhatsApp or Telegram. Students with adequate Internet connections can participate in scheduled synchronous classes, which are held according to students' schedules to avoid overlapping online classes. Students can also engage in self-paced asynchronous learning activities through the university's online learning platform (UFuture) and other online platforms like Google Meet or Microsoft Teams.

Though learning English via ODL is facilitated by the comfort of both asynchronous and synchronous environments, studies have shown that both teachers and students sometimes struggle. The struggles may come from either one or all the issues such as familiarisation with the use of online tools, the capacity to use the medium to draw maximum advantages, teachers being available at times of need, and the ability to provide feedback and quick responses to learners (Selvanathan et al., 2020; Krishnan et al., 2020). Therefore, educators must understand the students' perspective on the students' learning readiness, efficiency, self-motivation, and computer literacy skills to learn English via ODL.

\section{Context of the Present Study}

Presently, to complete one's education at UiTM, all undergraduate students have to complete three levels of English proficiency courses. Students must learn listening, speaking, reading, and writing skills in social and academic contexts as stipulated in the syllabus for English language proficiency courses. Furthermore, some language exercises, such as oral presentations, group discussions, and role-plays, require students to perform in front of the class. As part of the overall evaluation, students will evaluate their communicative ability, language usage, and task completion. Previously, all these were done face-to-face before the Covid-19 pandemic came and changed the whole scenario into a complete remote learning experience. Traditional design for language learning in a face-to-face interaction included real-time interaction, direct feedback, and a human touch (Perveen, 2016). However, using an ODL method of language learning can be challenging for students as they need to attend classes online and submit assignments and take tests online. According to Gillett-Swan (2017), one of the most challenging learning experiences virtually is to complete collaborative learning assignments that require group work, group presentations, and group evaluations. In online learning, students need to familiarise themselves with new applications, which can result in technology-related anxiety; being outside of one's comfort zone; (perceived) inequity in evaluation, especially in group assignments; and (perceived) inability or difficulty in peer interaction, particularly in presentations (Mpungose 2020; Gillett-Swan 2017).

Therefore, this study aims to examine UiTM students' ability to cope with learning English via ODL by looking at their preferred online learning tools, readiness, efficiency, selfmotivation, and computer literacy skills they possess to learn and to complete assignments and test online.

\section{Research Objectives}

This research project attempts to seek answers to the following research objectives:

1. To determine the student's preference in using ODL for English courses. 
2. To identify the relationship between students' preference for ODL for English courses and students' learning readiness, efficiency, self-motivation, and computer literacy skills.

3. To identify significant factors that affect student's preference in using ODL for English courses.

\section{Methodology}

\section{Theoretical Framework}

The theoretical model is illustrated in Figure 1. The dependent variable is the student's preference to learn English via ODL, while the independent variables are the student's learning readiness, efficiency, self-motivation, and computer literacy skills to learn via ODL.

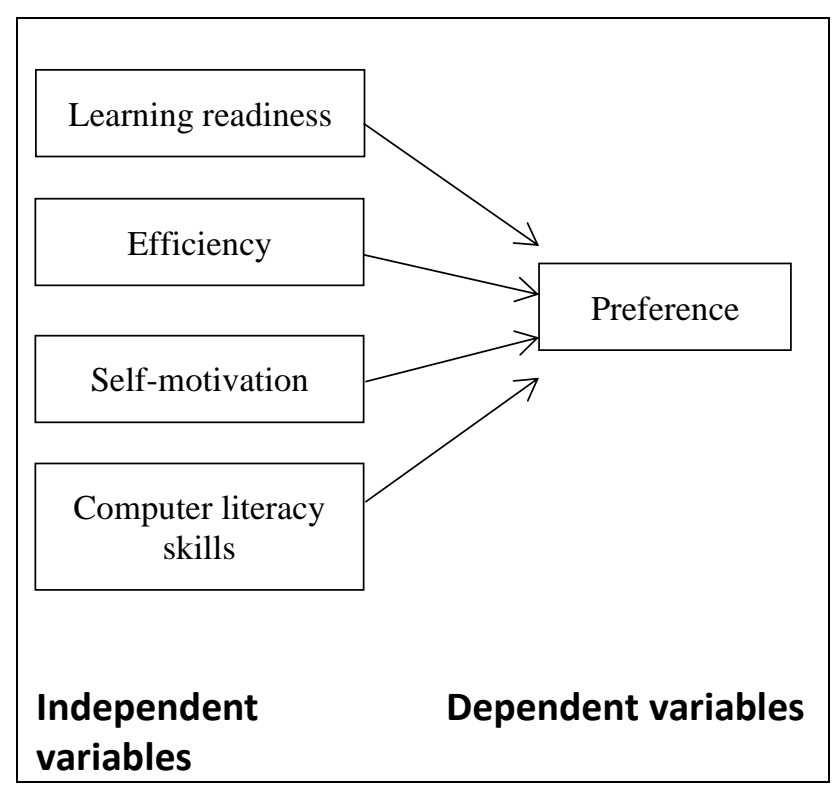

Figure 1. Theoretical Framework

Figure 1 shows the four key factors of this study that must be explained. Firstly, learning readiness refers to the learning preparedness of the students to participate in both the asynchronous and synchronous modes of learning. When a computer system or network system is lacking or down, students feel frustrated because they might not follow the lessons, upload assignments, or sit for a test online as prescribed by the course syllabus. This causes anxiety among lower Internet-skilled students.

Efficiency refers to student's perceived computer mastery to fulfil the English course requirements, such as retrieving materials from the repository site, submitting, and tracking assignments uploaded online, and sitting for tests online. Students may be digital natives when it comes to communicating and collecting information online, however for learning purposes, they need to know, for example, effective ways to prepare a presentation with audio or video embedded or record themselves role playing or being part of intellectual discourse. Students' varying levels of computer literacy can be detrimental to students who lack knowledge on the different skills needed to complete and submit assignments. Thus, adapting to the online environment can be challenging for some students (Gillett-Swan, 2017).

The feeling of fulfilment from the ODL learning experience and the desire to achieve their learning objective of learning English online are examples of self-motivation. Inspired 
students are more likely to engage in self-regulatory practices to help them achieve their objectives (Kemp et al., 2019). According to research, students with low motivation in online learning can spend more time completing assignments, turn in late assignments, or produce lower-quality work overall (Gay, 2018).

The last factor of this study is computer literacy skills which refer to students' ability to use with ease the hardware and software used for the ODL teaching and learning process. This is significant because a lack of confidence in the technology used for ODL among students can affect their learning outcomes and, subsequently, their results (Gay, 2018).

\section{Data Collection and Data Analysis}

Data from 1175 respondents were analysed with the Statistical Package for Social Sciences (SPSS) version 26, and the results were presented in both descriptive and inferential statistics. Frequency tables and graphs for percentages and figures were used in data analysis. The descriptive statistics shed light on the situations faced by the respondents, as the aim of the paper is to investigate students' perceptions of learning English through ODL. Meanwhile, inferential statistics illustrated the relationship and significance of variables used in this study.

This study used primary data by conducting surveys to measure the students' preference for Open Distance Learning (ODL) for English proficiency courses. Using convenience sampling, an online questionnaire was administered to diploma, and degree students enrolled in English courses $(n=1175)$ in local institution of higher learning. Convenience sampling is a type of nonprobability sampling in which respondents have an uneven chance of being selected by a random selection procedure. The results from this study provided summaries and conclusions about the sample involved and but the results cannot be used to infer to the population.

Respondents were asked to rate their degree of agreement on a Likert scale ranging from 1 to 5 , with 1 suggesting strong disagreement and 5 indicating strong agreement. Apart from that, the summated rating scale was used to gauge the overall student's response. Thus, this study calculated a total score that reflects the variables of students' learning readiness, efficiency, self-motivation, computer literacy skills, and preference for ODL for English courses.

Variables used in this study consist of preference as dependent and learning readiness, efficiency, self-motivation, and computer literacy skills as independent variables. As for data analysis, the association between these variables were discussed using descriptive statistics, correlation analysis, and multiple linear regression to attain the objectives of this study. Data collected in Google Form was screened and transferred to Statistical Package for Social Science (SPSS) for analysis. The results are organised according to the three research objectives as stated.

\section{Analysis and Findings}

This section discusses the findings of data analysis based on the research objectives, respectively. Table 1 depicts the demographic analysis of the respondents. A total of 1175 completed online survey forms were analysed, of which there were 919 (78.2\%) female and $256(21.8 \%)$ male respondents. More than half of the respondents, 625 (53.2\%), were diploma students, and the remaining 550 (46.8\%) were degree students. 
Table 1. Respondents' demographic background

\begin{tabular}{|l|l|l|l|}
\hline \multicolumn{2}{|l|}{ Variable } & Frequency & Percentage \\
\hline \multirow{2}{*}{ Gender } & Male & 256 & 21.8 \\
\cline { 2 - 4 } & Female & 919 & 78.2 \\
\hline $\begin{array}{l}\text { Education } \\
\text { level }\end{array}$ & Diploma & 625 & 53.2 \\
\cline { 2 - 4 } & Degree & 550 & 46.8 \\
\hline
\end{tabular}

\section{Exploratory Factor Analysis (EFA)}

A questionnaire was developed specifically to assess student inclination in language learning via open distance learning during COVID. Therefore, exploratory factor analysis (EFA) was used to identify the loaded items to those factors. EFA is a data reduction technique used to reduce many variables to a small set of underlying factors (Jamil et al., 2016). A KaiserMeyer-Olkin (KMO) test and Bartlett's sphericity test were conducted to verify whether the data set was suitable for factor analysis. These tests, when taken collectively, offer a minimal criterion that must be met before a factor analysis, or a principal components analysis may be performed. Table 2 showed that factor analysis is possible, as indicated by the KMO value of 0.932 and Bartlett's test of sphericity ( $p$-value 0.05 ).

Table 2. KMO and Bartlett's test

\begin{tabular}{|l|l|}
\hline $\begin{array}{l}\text { Kaiser-Meyer-Olkin } \\
\text { (KMO) }\end{array}$ & Bartlett's test \\
\hline 0.932 & 0.000 \\
\hline
\end{tabular}

Extraction communalities are estimates of the variance in each variable as depicted in Table 3 for the 18 items. High values indicate that variables fit well with the factor solution and should be retained in the analysis. According to Osborne (2014), the commonalities above 0.4 are acceptable, and the analysed instrument fulfils this criterion.

Table 3. Factor Communalities results

\begin{tabular}{|l|l|}
\hline Items & Extraction \\
\hline Item 1 & 0.595 \\
\hline Item 2 & 0.771 \\
\hline Item 3 & 0.683 \\
\hline Item 4 & 0.564 \\
\hline Item 5 & 0.734 \\
\hline Item 6 & 0.660 \\
\hline Item 7 & 0.635 \\
\hline Item 8 & 0.582 \\
\hline Item 9 & 0.598 \\
\hline Item 10 & 0.457 \\
\hline Item 11 & 0.595 \\
\hline Item 12 & 0.579 \\
\hline Item 13 & 0.657 \\
\hline Item 14 & 0.708 \\
\hline Item 15 & 0.669 \\
\hline Item 16 & 0.688 \\
\hline Item 17 & 0.711 \\
\hline Item 18 & 0.683 \\
\hline
\end{tabular}


Further, the EFA study indicates the first four principal components from the extracted solution with eigenvalues greater than one. It is supported by the scree plot, where it shows bend at the fourth component. These two methods, the value of eigenvalues and scree plot analysis, were used, and then, the number of factors in the data set can be obtained. Table 4 indicates the first eigenvalue equal to 7.844 and corresponds to 43.577 per cent of the variance in the data. The second eigenvalue is 1.487, corresponding to the second factor associated with 8.259 per cent of the variance. The successive eigenvalues are 6.725 and 5.717 , respectively, corresponding to the variance's 6.725 and 5.717 per cent. The cumulative percentage of the total variance explained by the factors extracted is 64.277 per cent which considerably reduces the complexity of the data set by using these four components with only $35.723 \%$ loss of information.

Table 4. Total Variance Explained

\begin{tabular}{|l|l|l|l|}
\hline Component & Eigenvalues & $\begin{array}{l}\text { Initial } \\
\text { Eigenvalues } \\
\text { Per cent of } \\
\text { Variance }\end{array}$ & $\begin{array}{l}\text { Cumulative } \\
\text { percentage }\end{array}$ \\
\hline 1 & 7.844 & 43.577 & 43.577 \\
\hline 2 & 1.487 & 8.259 & 51.836 \\
\hline 3 & 1.210 & 6.725 & 58.560 \\
\hline 4 & 1.029 & 5.717 & 64.277 \\
\hline & & & \\
\hline
\end{tabular}

Extraction Method: Principal Component Analysis

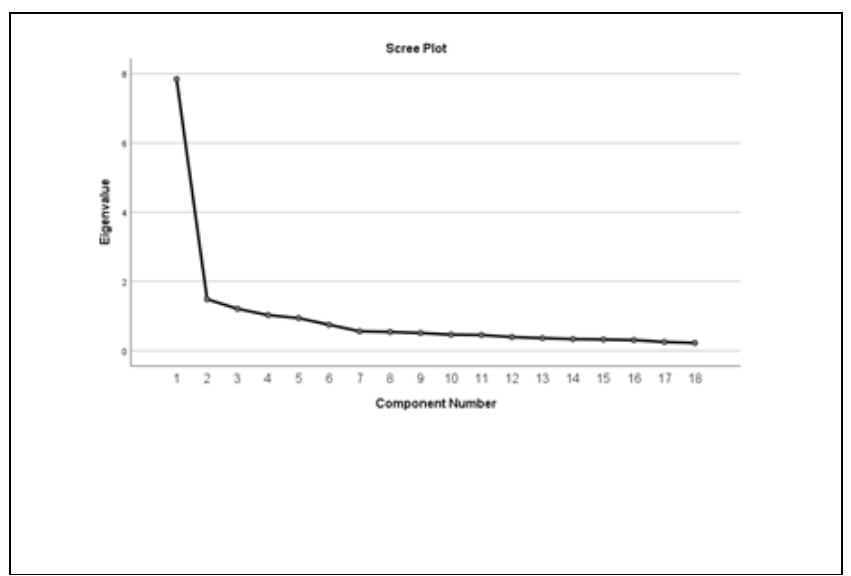

Figure 2. The scree plot was used to determine the number of factors to retain in EFA

Principal Component Analysis with Varimax rotation that produced the final 18 items suggested four factors that affect students' preference for ODL for English courses, as shown in Table 5. Seven items that loaded onto Factor 1 were labelled as "computer literacy skills." Six items that were loaded onto Factor 2 were labelled as "efficiency." Three items that were loaded onto Factor 3 were labelled as "learning readiness." Two items that were loaded onto Factor 4 were labelled as "self-motivation." 
Table 5. Rotated component matrix

\begin{tabular}{|l|l|l|l|l|}
\hline \multirow{2}{*}{ Items } & \multicolumn{4}{|l}{ Components } \\
\cline { 2 - 5 } $\begin{array}{l}\text { Item } \\
10\end{array}$ & $\mathbf{0 . 5 1 0}$ & 0.341 & 0.241 & -0.149 \\
\hline $\begin{array}{l}\text { Item } \\
12\end{array}$ & $\mathbf{0 . 4 9 4}$ & 0.487 & 0.313 & 0.019 \\
\hline $\begin{array}{l}\text { Item } \\
13\end{array}$ & $\mathbf{0 . 5 8 1}$ & 0.422 & 0.371 & 0.051 \\
\hline $\begin{array}{l}\text { Item } \\
15\end{array}$ & $\mathbf{0 . 7 7 3}$ & 0.213 & 0.161 & 0.015 \\
\hline $\begin{array}{l}\text { Item } \\
16\end{array}$ & $\mathbf{0 . 8 0 2}$ & 0.165 & 0.135 & 0.015 \\
\hline $\begin{array}{l}\text { Item } \\
17\end{array}$ & $\mathbf{0 . 8 1 0}$ & 0.150 & 0.108 & 0.143 \\
\hline $\begin{array}{l}\text { Item } \\
18\end{array}$ & $\mathbf{0 . 7 9 2}$ & 0.171 & 0.142 & 0.082 \\
\hline Item 4 & 0.253 & $\mathbf{0 . 5 9 2}$ & 0.330 & 0.201 \\
\hline Item 6 & 0.152 & $\mathbf{0 . 7 8 4}$ & 0.146 & -0.026 \\
\hline Item 7 & 0.172 & $\mathbf{0 . 7 6 0}$ & 0.119 & 0.115 \\
\hline Item 9 & 0.362 & $\mathbf{0 . 6 2 3}$ & 0.205 & 0.194 \\
\hline $\begin{array}{l}\text { Item } \\
11\end{array}$ & 0.482 & $\mathbf{0 . 4 9 8}$ & 0.335 & -0.050 \\
\hline $\begin{array}{l}\text { Item } \\
14\end{array}$ & 0.536 & $\mathbf{0 . 5 4 2}$ & 0.304 & 0.186 \\
\hline Item 1 & 0.126 & 0.277 & $\mathbf{0 . 7 0 6}$ & 0.064 \\
\hline Item 2 & 0.185 & 0.185 & $\mathbf{0 . 8 2 9}$ & 0.127 \\
\hline Item 3 & 0.268 & 0.142 & $\mathbf{0 . 7 6 8}$ & -0.010 \\
\hline Item 5 & -0.006 & -0.045 & 0.050 & $\mathbf{0 . 8 5 4}$ \\
\hline Item 8 & 0.116 & 0.338 & 0.082 & $\mathbf{0 . 6 6 9}$ \\
\hline
\end{tabular}

\section{Reliability Analysis}

A Cronbach alpha analysis was conducted on the questionnaire to check the items' internal consistency. A preliminary analysis of 18 items of the questionnaire accounted for a Cronbach alpha value of $\alpha=0.914$. Nunnally (1978) suggested that 0.7 is an acceptable value for a reliable construct. Therefore, the overall result of reliability analysis for this study was acceptable to indicate that the items in the questionnaire were reliable.

\section{Descriptive Statistics}

The mean value analysis was conducted to identify students' preference in using ODL for English courses (RO1). The result in Table 6 showed a moderate tendency in agreeing to students' preferences with a mean value of 2.829 and a standard deviation of 0.898 . This is supported by a skewness value of -0.153 , which indicates the distribution is slightly skewed to the left. 
Table 6. Descriptive statistics of student's preference in using ODL for English course

\begin{tabular}{|l|l|}
\hline Mean & 2.829 \\
\hline Standard deviation & 0.898 \\
\hline Skewness & -0.153 \\
\hline
\end{tabular}

\section{Correlation Analysis}

The bivariate correlation produces a correlation coefficient that measures the strength and direction of linear relationships between pairs of continuous variables. Notably, this study hypothesised a positive correlation between the dependent (preference to learn English via $\mathrm{ODL}$ ) and independent variables of this study (learning readiness, efficiency, self-motivation, and computer literacy skills) to one another (RQ2).

This study used the nonparametric test of Spearman's rank-order correlation to identify the relationship between students' preference in using ODL for English courses and students' learning readiness, efficiency, self-motivation, and computer literacy skills. A normality test was conducted before deciding to use the Spearman. The normality test indicates the distributions were not normally distributed since all $p$-values less than the significance level of 0.05 .

As seen in Table 7, the p-value is less than the predefined significance level of 0.01 . Therefore, reject the null hypothesis and conclude that there is a significant correlation between the two variables. Thus, this study showed an association between students' preference to learn English and their learning readiness, efficiency, self-motivation, and computer literacy skills. Below indicate all variables were significantly positive linear correlations (Reject $\mathrm{H}_{0}, \mathrm{p}$-value $<\alpha=0.01$ )

Table 7. Spearman's rank-order correlation

\begin{tabular}{|l|l|l|l|}
\hline & Variable & rho & $\begin{array}{l}\text { p- } \\
\text { value }\end{array}$ \\
\hline \multirow{3}{*}{ Preference } & $\begin{array}{l}\text { Computer literacy } \\
\text { skills }\end{array}$ & 0.746 & 0.000 \\
\cline { 2 - 4 } & Efficiency & 0.688 & 0.000 \\
\cline { 2 - 4 } & Learning readiness & 0.486 & 0.000 \\
\cline { 2 - 4 } & Self-motivation & 0.213 & 0.000 \\
\hline
\end{tabular}

\section{Multiple Linear Regression}

Standard multiple linear regression was used to answer the RO3. Preliminary analyses were conducted to ensure no violation of normality, linearity, multicollinearity, and homoscedasticity assumptions. This model purposely explores the linear relationship between student's preference $(y)$ in using ODL for English course and student's computer literacy skills $\left(x_{1}\right)$, efficiency $\left(x_{2}\right)$, learning readiness $\left(x_{3}\right)$, and self-motivation $\left(x_{4}\right)$ as further to identify factors that most affect student's preference in using ODL for English course. Analysis of Variance (ANOVA) indicated the model was fit $(F=613.179, p$-value $=0.000<0.05)$ with independent variables used in the model explaining 67.7 per cent of the variation in student's preference.

Table 8 represents the collinearity statistics showing all tolerance values were more than 0.10 , and variance inflation factor (VIF) values of less than ten indicated no multicollinearity problems exist to use multiple linear regression. 
Table 8. Collinearity Statistics

\begin{tabular}{|l|l|l|}
\hline \multirow{2}{*}{ Independent variables } & \multicolumn{3}{|l|}{ Collinearity Statistics } \\
\cline { 2 - 3 } & Tolerance & VIF \\
\hline $\begin{array}{l}\text { Computer literacy } \\
\text { skills }\end{array}$ & .430 & 2.325 \\
\hline Efficiency & .374 & 2.673 \\
\hline Learning readiness & .625 & 1.601 \\
\hline Self-motivation & .899 & 1.113 \\
\hline
\end{tabular}

This is supported by preliminary analysis conducted to ensure that there is no violation of the multicollinearity, highly correlated between independent variables of 0.90 and above (Pallant, 2016). Table 9 indicates that correlation analysis showed that independent variables were significantly low to moderate positive linear correlation.

Table 9. Correlation analysis among independent variables

\begin{tabular}{|l|l|l|l|l|}
\hline & $\begin{array}{l}\text { Computer } \\
\text { literacy } \\
\text { skills }\end{array}$ & Efficiency & $\begin{array}{l}\text { Learning } \\
\text { readiness }\end{array}$ & $\begin{array}{l}\text { Self } \\
\text { motivation }\end{array}$ \\
\hline $\begin{array}{l}\text { Computer } \\
\text { literacy } \\
\text { skills }\end{array}$ & 1.000 & & & \\
\hline Efficiency & $0.701^{* *}$ & 1.000 & & \\
\hline $\begin{array}{l}\text { Learning } \\
\text { readiness }\end{array}$ & $0.488^{* *}$ & $0.537^{* *}$ & 1.000 & 1.000 \\
\hline $\begin{array}{l}\text { Self } \\
\text { motivation }\end{array}$ & $0.160^{* *}$ & $0.287^{* *}$ & $0.161^{* *}$ & \\
\hline
\end{tabular}

(p-value $=0.000<0.01)$

Table 11 indicates all independent variables entered in the model, variable computer literacy skills $(t=21.019, p=0.000<0.05)$, efficiency $(t=10.803, p=0.000<0.05)$, learning readiness ( $t=2.689, p=0.007<0.05)$ and self-motivation $(t=2.474, p=0.014<0.05)$ made statistically significant towards student's preference in using ODL for English course.

In addition, all significance variables positively correlated with students' preference in using ODL for English courses. This means that students' readiness to participate in both asynchronous and synchronous environments, strong self-motivation, and computer literacy can help students overcome the challenges in an online distance learning environment. Furthermore, the study shows that students face ease in fulfilling the English course requirements such as completing assignments and sitting for online tests.

Based on standardised coefficients beta, computer literacy skills recorded the highest standardised coefficient (Beta $=0.533$ ). Therefore, computer literacy skills are the most significant variable for students' preference for ODL for English courses in the model. This appears to directly impact students' desire to participate in the learning process and overcome the challenges in an online distance learning environment. Based on the unstandardised coefficients $\beta$, the estimated coefficient value was $\beta_{0}=-1.146, \beta_{1}=0.183, \beta_{2}$ $=0.124, \beta_{3}=0.043$ and $\beta_{4}=0.046$. The specific regression model for this study is shown in Table 10.

$y=\beta_{0}+\beta_{1} x_{1}+\beta_{2} x_{2}+\beta_{3} x_{3}+\beta_{4} x_{4}$ 
$y=-1.146+0.183 X_{1}+0.124 X_{2}+0.043 X_{3}+0.046 X_{4}$

Table 10. Regression coefficient, t-statistics, and $p$-value

\begin{tabular}{|l|l|l|l|l|}
\hline & $\begin{array}{l}\text { Unstandardised } \\
\text { Coefficients }\end{array}$ & $\begin{array}{l}\text { Standardised } \\
\text { Coefficients }\end{array}$ & t & Sig. \\
\cline { 2 - 5 } & $\mathrm{B}$ & Beta & -7.226 & .000 \\
\hline $\begin{array}{l}\text { (Constant) } \\
\begin{array}{l}\text { Computer } \\
\text { literacy } \\
\text { skills }\end{array}\end{array}$ & -1.146 & .183 & 21.019 & .000 \\
\hline Efficiency & .124 & .293 & 10.803 & .000 \\
\hline $\begin{array}{l}\text { Learning } \\
\text { readiness }\end{array}$ & .043 & .057 & 2.689 & .007 \\
\hline $\begin{array}{l}\text { Self- } \\
\text { motivation }\end{array}$ & .046 & .043 & 2.474 & .014 \\
\hline
\end{tabular}

Overall, the study shows a positive relationship between the dependent variable of students' preference for using ODL to learn English and the four independent variables in which both variables move in tandem. Table 11 represents a summary of the regression findings.

Table 11. Summary of the regression findings

\begin{tabular}{|l|l|}
\hline Model & Findings \\
\hline $\begin{array}{l}\text { Computer } \\
\text { literacy skills }\end{array}$ & $\begin{array}{l}\text { As the rating scale increase in computer literacy } \\
\text { skills, so does student's preference in using ODL. }\end{array}$ \\
\hline Efficiency & $\begin{array}{l}\text { As the rating scale increase in efficiency, so does } \\
\text { student's preference in using ODL. }\end{array}$ \\
\hline $\begin{array}{l}\text { Learning } \\
\text { readiness }\end{array}$ & $\begin{array}{l}\text { As the rating scale increase in learning readiness, } \\
\text { so does student's preference in using ODL. }\end{array}$ \\
\hline $\begin{array}{l}\text { Self- } \\
\text { motivation }\end{array}$ & $\begin{array}{l}\text { As the rating scale increase in self-motivation, so } \\
\text { does student's preference in using ODL. }\end{array}$ \\
\hline
\end{tabular}

\section{Conclusion}

During the Covid-19 pandemic, students had to dive into the ODL learning method without much skills and knowledge, and this study showed that students perceived that their level of learning readiness, self-motivation, and computer skills were insufficient to cope with ODL. In addition, students also faced challenges when it came to the efficiency variable, which covered the ability to retrieve materials from the repository site, submit and track assignments uploaded online and sit for tests online.

The findings of this study concur with that of (Perveen, 2016), which found that lack of computer education was a significant concern because not all students have high computer literacy. Most students have the basic skills but not the advanced skills needed to complete assignments and tests in ODL. The respondents in this study were mainly taught using Google classroom, Microsoft teams, or UFuture (institutional LMS). Therefore, students faced difficulties managing the different platforms used by different lecturers, and such(so) needed time to learn the computer and technology skills needed for online classes. Furthermore, as students too(also) needed to record and upload presentations for assessments or assignments, such as role-play, a group forum, oral reviews of movies, and others, students 
needed more than the basic computer skills to follow online lectures. They lacked the skills to record their presentation, embed video or audio to the PowerPoint presentation, and others. This claim is substantiated by a study conducted by Aguilera-Hermida (2020), which found that one of the reasons students were not in favour of ODL is because the lack of skills hampered them in using the online application to complete assignments and that they had to spend more time learning to use the new applications. Because of that, they had to spend more money to subscribe to better and reliable internet service, which provides faster internet connectivity (Juhary, 2020).

Learning occurs using the hybrid method of asynchronous or synchronous. This study shows that this hybrid method seems favourable to the students. The study indicated that students needed instructor feedback and guidance to complete assignments throughout learning sessions during the pandemic. This study also found that students were generally motivated to learn English online.

Overall, this study found that students were in favour of learning English via ODL. Therefore, educators and administrators need to pay attention to the kind or type of assignments assigned online and how online tests are conducted so that students are not hampered by internet speed or lack of knowledge on the online application to complete assignments. More research must be conducted to explore and know how to improve online assessments and, under the circumstances, produce greater fairness for all students.

\section{References}

Abu Karim, M. (2020). UiTM moves to online learning mode. New Straits Times Online. https://www.nst.com.my/education/2020/04/586565/uitm-moves-online-learningmode

Aguilera-Hermida, P. (2020). College students' use and acceptance of emergency online learning due to COVID-19. International Journal of Educational Research Open, 1(August), 100011. https://doi.org/10.1016/j.ijedro.2020.100011

Gay, G. (2018). Fixing the 'Ready' in E-Learning Readiness. In M. Sinecen (Ed.), Trends in Elearning (pp. 137-144). IntechOpen. https://doi.org/10.5772/intechopen.74287

Gillett-Swan, J. (2017). The Challenges of Online Learning: Supporting and Engaging the Isolated Learner. Journal of Learning Design, 10(1), 20. https://doi.org/10.5204/jld.v9i3.293

Gonzalez, T., De la Rubia, M. A., Hincz, K. P., Comas-Lopez, M., Subirats, L., Fort, S., \& Sacha, G. M. (2020). Influence of COVID-19 confinement on students' performance in higher education. PLOS ONE, 15(10 October), 1-23. https://doi.org/10.1371/journal.pone.0239490

Jamil, N. I., Baharuddin, F. N., Sulaiman, T., Rosle, A., \& Harun, A. (2016). Exploratory Factor Analysis-Key to a Successful Mentoring Relationship. Journal of Advanced Research in Business and Management Studies, 2, 11-21.

Javid, C. Z., Althobaiti, N. S., \& Al-malki, E. A. (2021). A Comparative Investigation of the Impact of Effective Online Teaching Strategies Practiced during Corona Pandemic in Ensuring Sustainable Pedagogy. Universal Journal of Educational Research, 9(1), 17-31. https://doi.org/10.13189/ujer.2021.090103

Juhary, J. (2020). Emergency Remote Teaching during COVID-19 Pandemic: Roles of Educators in Malaysia. In E-Learning and Digital Education in the Twenty-First Century - Challenges and Prospects (pp. 1-15). https://doi.org/10.5772/intechopen.95071 
Kemp, A., Palmer, E., \& Strelan, P. (2019). A taxonomy of factors affecting attitudes towards educational technologies for use with technology acceptance models. British Journal of Educational Technology, 50(5), 2394-2413. https://doi.org/10.1111/bjet.12833

Krishnan, I. A., Ching, H. S., Ramalingam, S. J., \& Maruthai, E. (2020). Challenges of Learning English in 21st Century: Online vs . Traditional During. Malaysian Journal of Social Sciences and Humanities (, 5(9), 1-15.

Mpungose, C. B. (2020). Emergent transition from face-to-face to online learning in a South African University in the context of the Coronavirus pandemic. Humanities and Social Sciences Communications, 7(1), 1-9. https://doi.org/10.1057/s41599-020-00603-x

Muda, S., \& Yee, B. (2019). Perceived challenges in open and distance learning among nursing students of Open University Malaysia: A descriptive analysis Perceived challenges in open and distance learning among nursing students of Open University Malaysia : A descriptive analysis. International Conference on Education (ICE 2019), January, 429440.

Perveen, A. (2016). Synchronous and Asynchronous E-Language Learning: A Case Study of Virtual University of Pakistan. Open Praxis, 8(1), 21-39. https://doi.org/10.5944/openpraxis.8.1.212

Rizun, M., \& Strzelecki, A. (2020). Students' Acceptance of the COVID-19 Impact on Shifting Higher Education to Distance Learning in Poland. International Journal of Environmental Research and Public Health, 17, 6468. https://doi.org/10.3390/ijerph17186468

Selvanathan, M., Hussin, N. A. M., \& Azazi, N. A. N. (2020). Students learning experiences during COVID-19: Work from home period in Malaysian Higher Learning Institutions. Teaching Public Administration, 5(2), 34-50. https://doi.org/10.1177/0144739420977900

Shanthi, A., Adnan, A. A., Jamil, N. I., Nadira, A., \& Sharminnie, E. (2021). Exploring University Students ' Acceptance of Open Distance Learning Using Technology Acceptance Model ( TAM ) Exploring University Students ' Acceptance of Open Distance Learning Using Technology Acceptance Model ( TAM ). International Journal of Academic Research in Business and Social Sciences, 1(10), 250-262. https://doi.org/10.6007/IJARBSS/v11i10/11009

Shanthi, A., Adnan, A. A., Jamil, N. I., \& Rosle, A. N. (2021). Technology Acceptance Model (Tam) - As A Guide to Design Online Distance Learning for University Students. ESTEEM Journal of Social Sciences and Humanities.

Yazon, A. D., \& Callo, E. C. (2021). Assessing Teacher's Knowledge, Self-efficacy, and Practices ( KSP ) in Adopting Flexible Learning during the Covid-19 Pandemic. Universal Journal of Educational Research, 9(1), 136-144. https://doi.org/10.13189/ujer.2021.090115

Yen, T. T. F. (2020). The Performance of Online Teaching for Flipped Classroom Based on COVID-19 Aspect. Asian Journal of Education and Social Studies, 8(3), 57-64. https://doi.org/10.9734/AJESS/2020/v8i330229 